JOURNAL OF SECURITY AND SUSTAINABILITY ISSUES

ISSN 2029-7017/ISSN 2029-7025 (online)

2020 Volume 9 Number May

http://doi.org/10.9770/jssi.2020.9.M(12)

Scopus ${ }^{\circ}$

\title{
KNOWLEDGE SHARING BEHAVIOR BETWEEN SELF-LEADERSHIP AND INNOVATIVE
} BEHAVIOR

\author{
Hindah Mustika $^{1}$, Anis Eliyana ${ }^{2}$, Tri Siwi Agustina ${ }^{3}$, Ririn Tri Ratnasari ${ }^{4 *}$ \\ ${ }^{1234}$ Faculty of Economics and Business. Universitas Airlangga, Surabaya. Indonesia \\ ${ }^{I}$ Sekolah Tinggi Ilmu Ekonomi Indonesia (STIESIA) Surabaya \\ E-mail: ${ }^{4 *}$ ririnsari@feb.unair.ac.id (Corresponding author)
}

Received 18 October 2019; accepted 20 March 2020; published 30 May 2020

\begin{abstract}
Purpose examine and analyze the internal factors are knowledge sharing self-efficacy, self leadership, knowledge sharing behavior which is a determinant of innovative behavior. Innovative behavior is the variable of interest in the company that produces classic and this becomes a success and a means to sustain in the competition for very competitive industry. Design / methodology / approach This research method uses a quantitative approach to structural equation model of partial least square (PLS-SEM) as a tool to test and analyze, the respondents in this study amounted to 90 from various divisions. Internal factors that have a role to innovative behavior. Findings This study get the result that knowledge sharing self-efficacy and self-leadership has a direct influence on knowledge sharing behavior. Only the selfefficacy of knowledge sharing behabior does not have a direct influence on innovative behavior. Variable knowledge sharing behavior in this study could be the moderator of knowledge sharing self-efficacy and self-leadership to innovative behavior.Research limitations / implications The study was limited to one company that has been selling its products to foreign countries in the form of a classic product. The existence of multiple variables of a strong internal factors that become determinants of innovation behavior and is coherent with other studies but still on innovation behavior.Practical implications Companies that introduce innovative behavior must consider the importance of internal factors that can sustain the company in the face of competition is already clear today is globalization. Globalization is not inevitable, to achieve and maintain their co-factors needed to become an influence. Originality / value The research indicates the difference variables on internal factors, as it explores the innovative behavior in terms of behavior, because behavior is the feedback to be received directly by the company. On the other hand is expected to be added in the form of moderator variables gender difference (female or male) that will get the results (male and female) is more dominant
\end{abstract}

Keywords: innovative behavior; knowledge sharing behavior; knowledge sharing self-efficacy; self leadership

Reference to this paper should be made as follows: Mustika, H., Eliyana, A., Agustina, T.S., Ratnasari, R.T. 2020. Knowledge sharing behavior between self-leadership and innovative behavior. Journal of Security and Sustainability Issues, 9(M), 148-157.

http://doi.org/10.9770/jssi.2020.9.M(12)

JEL Codes: O35

\section{Introduction}

One product that was environmentally friendly products made from natural ingredients derived from nature, one watches. This product can be regarded as an innovation eco watch. The term eco watch itself is an environmentally friendly product, this is because Matoa in producing products by using scrap materials selection timber industry (wood industry waste). The reason is because the ebony wood waste is not easily damaged, especially not easily perforated or Tropos. In addition, this species including black wood, strong and visible has its own charm that is so more memorable exotic premium and elegant when seen. Another reason made from wood waste,

The process to get something that is unique and has its charms required an innovative behavior. Innovative behavior is the ability of individuals in completing tasks and assignments using the workings of combining procedures, practices and techniques. The innovative behavior of individual behavior that everyone focused on the circumstances, deliver, and the application of new things that will bring benefits in the organization. Can say 
JOURNAL OF SECURITY AND SUSTAINABILITY ISSUES

ISSN 2029-7017/ISSN 2029-7025 (online)

2020 Volume 9 Number May

http://doi.org/10.9770/jssi.2020.9.M(12)

something new in the form of a creative idea or technology in new product development and the development of the administration with the main objective to improve the working relationship (Haseeb et al., 2020).

There two (2) factors that form the innovative stimulus behavior is internal and external factors. The internal factors may be viewed on the type of personality and individual style in solving the problem. External factors in this case the leadership, support for innovation ber, and psychological demands of the job. In this study, more focused on the internal factors are knowledge sharing self-efficacy (Hsiao, Brouns, Bruggen, \& Sloep 2012), self-leadership (Asfar B, Mamoon M 2017); Carmeli 2006), and knowledge sharing behavior (Tseng, \& Kuo, 2014; Ofori, Osei, Mensah, Affum, 2015)

Knowledge sharing behavior is an activity or process by which tacit and explicit knowledge conveyed or for all other individuals (Becerra et al 2016). According (Madanchian, $M$ et al 2015) knowledge sharing is very important because it could be competitive for the company, in this case the innovation is obtained from the sharing of knowledge from one person to another person in an organization. The knowledge sharing, then it could have a significant influence on an individual's competence in the organization. On the other hand, other than as a stimulus of innovation behavior turned out to be knowledge sharing self-efficacy and self-leadership as antecendents of knowledge sharing behavior. Knowledge sharing behavior can be described as part of the formulation of strategies formulated to reduce or avoid the obstacles that will occur either within the organization or outside the organization, either by an organization or the employee himself. Processing knowledge can be through knowledge sharing behavior which is a mandatory requirement is owned by an organization, because organizations that have confidence in the ability to absorb knowledge can manage them and exploit the knowledge on the resources which will generate a competitive advantage that will have an impact on the existence of organizations working in the midst of competition and changes that can not be predicted.

Other internal factors, namely knowledge sharing self-efficacy by (Kurbago 2010) "efficacy beliefs play a central role in the cognitive regulation of motivation". In this case the efficacy has an important role in regulating one's motivation. (Kurbago, S 2010) "Perceived self-efficacy contributes to motivation ", which means that the efficacy of a person having major impact on the behavior of individuals, one of which is motivation. Self-efficacy in this study explained to three (3) dimensions of self-efficacy magnitude, generality and strength. Magnitude itself is a level or a level where when someone believes that effort or behavior can be performed. Strength is a self-confidence that are within the individual that can make happen for getting individual performance. Generality is the freedom of self efficay form that is in the individual to be used in other situations are different. So to say that the higher the level of self-efficacy individuals, the higher the level of an individual adjustment to the situation at hand. Knowledge sharing is an individual's perception of self-efficacy will be able to perform his belief that sharing behavior or actions. Knowledge sharing self-efficacy may affect the actions to be carried out, the amount of effort and resilience when faced with obstacles or difficulties. So to say that people with high self-efficacy choose to do business bigger and unyielding. So to say that the higher the level of self-efficacy individuals, the higher the level of an individual adjustment to the situation at hand. Knowledge sharing is an individual's perception of self-efficacy will be able to perform his belief that sharing behavior or actions. Knowledge sharing self-efficacy may affect the actions to be carried out, the amount of effort and resilience when faced with obstacles or difficulties. So to say that people with high self-efficacy choose to do business bigger and unyielding. So to say that the higher the level of self-efficacy individuals, the higher the level of an individual adjustment to the situation at hand. Knowledge sharing is an individual's perception of self-efficacy will be able to perform his belief that sharing behavior or actions. Knowledge sharing self-efficacy may affect the actions to be carried out, the amount of effort and resilience when faced with obstacles or difficulties. So to say that people with high self-efficacy choose to do business bigger and unyielding. Knowledge sharing is an individual's perception of self-efficacy will be able to perform his belief that sharing behavior or actions. Knowledge sharing self-efficacy may affect the actions to be carried out, the amount of effort and resilience when faced with obstacles or difficulties. 
JOURNAL OF SECURITY AND SUSTAINABILITY ISSUES

ISSN 2029-7017/ISSN 2029-7025 (online)

2020 Volume 9 Number May

http://doi.org/10.9770/jssi.2020.9.M(12)

Self leadership is a process that affects the self (self influence) through a behavior or action that may or able to be done by an individual or a person to reach a destination (self-direction) and motivation (self motivation) are required to complete the work (Manz, 1986, Manz and Neck, 2004). Self leadership is composed of specific behavioral and cognitive strategies designed to influence personal wherein effectively. In general in this strategy are grouped into three main categories, namely strategy centered on the behavior (behavior focus strategy), natural reward strategies, and strategic thinking patterns konstruktiff (constructive thought pattern strategies) (Manz and Neck, 2004). Von Glinow on the other hand, mentions that self leadership includes mental exercise (mental practice), designing natural rewards, monitor themselves (self-monitoring), self-reinforcement and self-cueing. The first part in self leadership is to develop expectations for one's work (personal goal setting). This section to identify partictular expectations to be achieved, relevant and challenging expectations. Something that makes this case different is the expectation itself was compiled, so not a result of joint discussions with the boss or colleagues. (Mc Shane \& Von Glinow, 2003), the next step is a constructive thought patterns (constructive thought patterns). So before starting an activity and when people would carry it out, employees should have positive thoughts about the job and as well as the completion of the work. So that employees will be more motivated and ready to finish the job once they have made 'positive selftalk' and 'mental imagery' (Mc Shane \& Von Glinow, 2003)

\section{Literature Review and Hypotheses Development}

\section{Innovative Behavior}

Innovative behavior something that often arise when employees face a challenge in the activities or work, getting ample opportunity to carry out their duties and responsibilities. (Begonja 2016) states a series of innovative behavior of an activity or behavior that gradually work done by workers or by individuals who are working to develop and improve the behavior of an effective and efficient work. There are several steps in creating innovative behavior that includes: 1 . To know and properly interpret the scope of employment and potential problems being faced and that could be a strong sense.2. Have a high awareness of the quality of work and creative has a solution if it has problems.3. Creating a network of cooperation and agreement together to bring innovative proposal of any improvement in the process of group work together. 4. Aplicated or implementing the recommended improvements in employment.

According to (George and Zhou 2001) stated that the character of innovative behavior include the desire of knowledge about new technologies, processes, new ideas and generate creative ideas, promote and to strive idea possessed to others, investigate and provide the necessary resources to realize the new ideas you have, develop plans and schedules are pretty good to realize new ideas. Innovative behavior has an indicator which, according to (Begonja 2016) that there are three (3) consisting of: 1) Opportunities, saw opportunities for employees to identify various possibilities or opportunities, it can be seen problems in work patterns already in progress, the needs of consumers (customers) are not met, or an indication of the changing trends. 2) Idea, at this stage, employees said the new concept is expected to improve the destination. It issued a new idea or renew services, meeting with clients and supporting technology. The key in issuing the idea is to combine and reorganize information and concepts that have been there before to solve problems or improve performance. 3) Defend, in this case to develop dan implement new ideas, the employee must have a behavior or actions based on the outputs (results). Convergen innovative behavior consists of effort and work hard to become champion. So individuals who have behavioral champions will remove all creative ideas. It's become a champion is to have a positive influence on employees to be able to create or attract customers.

\section{Knowledge Sharing Behavior}

Managing knowledge is important and should be done by the organization if the organization wants to have the advantage competitive (Wang and Noe, 2010; Wichitsathian, SNakruang, 2019). So an organization that already has something interesting and unique knowledge, it will have a chance to get in the competitive industrial market. Knowledge management is based on systematic activity offer management through the acquisition, use, sharing, 


\section{JOURNAL OF SECURITY AND SUSTAINABILITY ISSUES}

ISSN 2029-7017/ISSN 2029-7025 (online)

2020 Volume 9 Number May

http://doi.org/10.9770/jssi.2020.9.M(12)

storage, retrieval and knowledge development in order to generate new ideas that generate innovation. The success of knowledge management practices rely heavily on knowledge sharing behaviors that occur among employees within an organization. Knowledge sharing behavior a behavior that is displayed by the members of the group to receive or provide the resources, knowledge, experience or something positive to or from other members (Wasko \& Faraj, 2000, 2005: Tseng, \& Kuo, 2014).

Knowledge is a combination of several elements, which consist of insight expertise, experience, contextual information, and values that provide a framework for evaluating and incorporating new skills and information. Knowledge can be defined as "information in the form of ideas, facts, expertise and judgment are processed by an individual which includes ideas, facts, skills, and assessment relevant to the individual, team, and organizational performance" (Wang and Noe 2010 ). Knowledge is derived and applied in one's mind, it is reflected in organizational routines, processes, practices, and norms that exist. Experts have outlined two (2) types of knowledge (Penrose, 2009;. Jain et al, 2015; Wang and Noe, 2010). First, explicit knowledge which is a kind of knowledge of concrete, usually with simple and well expressed in the form of language (words, numbers and other symbols) or codified, easily articulated and easily transferred to others through writing or verbal communication. Secondly, tacit knowledge that is not like eksplist knowledge, tacit knowledge, based on the knowledge that is embedded in the mind about a man, is not easy and nice to be transferred to another person (Jain et al, 2015).

Lin, 2007 states that knowledge sharing can be defined as a culture of social interaction involving knowledge transfer, sharing of experiences and skills among members of the organization. All kinds of knowledge sharing behavior can occur on both levels, individuals (members of the organization) and the organization itself. (Hoof and Weenen 2004) states that knowledge sharing is a process by which individuals mutually mempertuarkan their knowledge (tacit and explicit knowedge). Knowledge sharing individuals in the information system or information technology, the longer will be able to provide updates to the overall knowledge of the organization, which in turn will provide a unique organizational characteristics for the company's competitors and can further improve performance. In line with research conducted by (Lin 2007); (Yu, Fang and Chieh 2013).

\section{H1: knowledge sharing behavior significantly influence innovation behavior on employees of PT. Matoa Indonesia in Bandung.}

\section{Knowledge sharing self-efficacy}

Self-efficacy is a complex cognitive assessment of the ability of a person or individual in the days to come to organize and choose behaviors or actions required to achieve certain goals. self-confidence is one's belief in his ability to provide valuable knowledge for others, as stated by (Shaari, Rahman and Rajab 2014). Self-efficacy are stronger in person or individual underlying patterns of thought, feeling, and encouragement in itself that would reflect all the skills that individuals have. Self-efficacy also provide a strong heavy foundation for individuals to evaluate themselves in order to face or resolve the demands of work and dynamic competition. Self-efficacy alone can bring a sense of optimism that the end goal can cause overflow or positive emotions and avoid individual or a person of emotions negative emotions such as depression (Luszczynska, Scholz \& Schwarzer, 2005). Individuals or someone who has a high self-efficacy will build a good emotional condition and conducive for themselves to solve the problem at hand. So with a good emotional state, then that person will be more capable and accept whatever the problems and overcome the stress they felt.

Self-efficacy can be referred to as a trigger for individuals to perform the behavior in order to achieve the desired goal. Self-efficacy in the field of crafts or skills related to belief employees or individuals ability to complete activities or tasks, with their own organizations and others, so it can be concluded that the higher self-efficacy which is owned by the individual, then the individual will self-efficacy one can increase when getting achievement which experienced individual or that individual, the experience gained individual or person when he saw other people with 


\section{JOURNAL OF SECURITY AND SUSTAINABILITY ISSUES}

ISSN 2029-7017/ISSN 2029-7025 (online)

2020 Volume 9 Number May

http://doi.org/10.9770/jssi.2020.9.M(12)

characteristics similar to him in achieving success while completing a specific task, verbal support to someone in order to complete the task well and psychological turmoil when people are in a state of distress. Self-efficacy in this case affect the selection task can be trusted, effort, perseverance, joy and accomplishment Schunk, D. H., \& Zimmerman, B. J. 1998 . Innovation itself requires a sense of ductile behavior of a self-efficacy. Innovation requires a great effort for a long period but with uncertain outcome Bandura, 1994. This is supported by research that mentions the existence of a positive relationship between self-efficacy and innovation behavior of a teacher in Taiwan (Hsiao HC, et al, 2011). Innovation itself requires a sense of ductile behavior of a self-efficacy. Innovation requires a great effort for a long period but with uncertain outcome Bandura, 1994. This is supported by research that mentions the existence of a positive relationship between self-efficacy and innovation behavior of a teacher in Taiwan (Hsiao HC, et al, 2011). Innovation it self requires a sense of ductile behavior of a self-efficacy. Innovation requires a great effort for a long period but with uncertain outcome Bandura, 1994. This is supported by research that mentions the existence of a positive relationship between self-efficacy and innovation behavior of a teacher in Taiwan (Hsiao HC, et al, 2012).

\section{H2: Self-efficacy significantly influence innovation behavior on employees of PT. Matoa Indonesia in Bandung}

Self-efficacy the self-confidence of the individual or someone in his ability that can contribution valuable knowledge for others, as stated by (Shaari, Rahman and Rajab 2014), and (Momeni, Ebrahimpour and Ajirloo 2014). In some studies, self-efficacy is a self-evaluation and self-confidence in the skills and personal ability to respond to inquiries undertaken by other members, and to provide knowledge. Through knowledge sharing useful, people feel more confident in the activities (Bandura, 1982). Self-efficacy is a form of self-evaluation that affect decisions about what behaviors should be done (Igbaria \& Iivari, 1995). Self-efficacy has received tremendous attention across various disciplines (c.f., Mozammel, Ahmed, Slade \& Zaman, 2018). In general, the perceived self-efficacy plays an important position in influencing the motivation and knowledge sharing. The findings showed that self-efficacy had a significant positive effect on knowledge sharing, it is supported also by (Alhady et al 2011) that knowledge sharing is influenced by self-efficacy.

\section{H3: Self-efficacy significantly influence knowledge sharing the employees of PT. Matoa Indonesia in Bandung.}

\section{Self Leadership}

The concept of self-leadership is a set of behaviors that is based on social learning theory and the theory of goal setting. (Mc Shane \& Von Glinow, 2003). Self leadership describe the process of influencing oneself (self influence) through an act that the person is able to do and achieve a direction of self (self-direction) and motivation (self motivation) are required to complete the work (Manz and Neck, 2004).

It is too soon to say that self-leadership has components that are useful, but the reality says that implementation of the 'self-leadership' itself generally can increase confidence in yourself, motivation and performance. A research on "sports psychology" indicates that the "self-set goals" and "constructive thought process" improve individual performance. One example is a young ice skater who trained the "self-talk" can get an increase in achievement year. You could say in a study showing that the average or nearly all Olympic athletes rely on mental exercise and positive self-talk that is used to get the performance he wanted. (Baughman, 2000). So any one of the advantages that dipeorleh of self leadership, that leadership can be learned self. Training programs can help workers to improve their ability of self leadership. Organizations can also improve self leadership by providing adequate autonomy and rewards to encourage self leadership behaviors (Bradshaw, R. et al 2015).

Self leadership is a process where employees are motivated and reaching out to achieve the expected behavior (Kor, 2016). According (Oduntan 2014), self leadership and work tasks have a positive relationship. Self-leadership 
refers to the internal process, where an individual knowledge and constructive move towards the creation of the thoughts and intents of the desired changes, improvements and innovation behavior (Carmeli, Weisberg \& Meiter 2006). In this case supported by several studies showing that self positive effect on innovation leadership behavior (Tasan 2013); (Khodaverdi 2015); (Widyani, Sugianingrat, and Sarmawa 2016); (Kor 2016); (Park, Moon and Hyun 2014); (Hosseini, Bathae and Mohammadzadeh 2014); (Widyani 201), (Ziyae and Heydari 2016)

H4: Self leadership significantly influence innovation behavior on employees of PT. Matoa Indonesia in Bandung

Self leadership a combination of the theory of self-regulation, self-control and self-management which according to (Manz and Neck 2004) is divided into three categories consisting of behavior focused strategies, natural reward strategies and strategies of constructive thought patterns. According to (Manz 1986) self leadership process whereby a person makes a decision based on the capacity and ability, although someone motivated to carry out and complete the task, but not everyone is able to demonstrate his knowledge sharing at its final destination on the innovation behavior. Self leadership is a process whereby a person motivated and reaching out to get the desired behavior (Kor, 2015). Based on research conducted by (Masood, Shahzad and Nosheen, 2011)

\section{H5: Self leadership significant effect on knowledge sharing the employees of PT. Matoa Indonesia in Bandung}

The research model

The current study has a framework in which this framework as the basis for the preparation of this hypothesis is as follows (see figure 1).

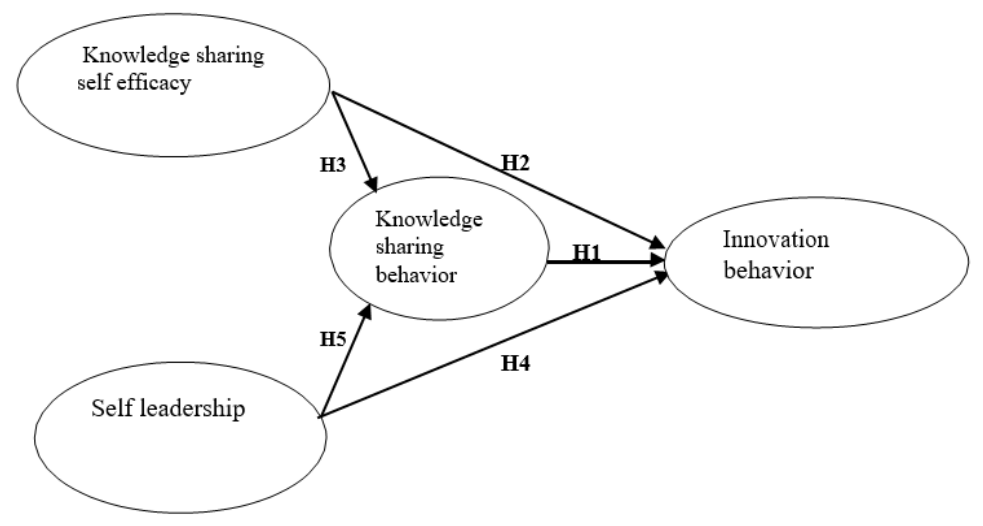

Figure 1. Reseach model

\section{Methodology}

The population there is 90 employees of PT. Matoa Indonesia, each variable has several indicators. Variables of innovative behavior has seven indicators, knowledge sharing has six indicators, knowledge sharing self-efficacy consists of six indicators, self leadership consists of 9 indicators. All items within each indicator is measured using a Likert scale $(1=$ strongly disagree, $5=$ strongly agree). Data analysis in this study using structural equation modeling (SEM) partial least square (PLS) with smart PLS (3.0). 


\section{Result and Discussion}

The result showed that all indicators in the study variables knowledge sharing self-efficacy, self leadership, knowledge and innovative behavior sharing have a consistent and valid measurement. Can say the value of coefficient loading outer has a range of 0.567 to 0.916, the value of Cronbach alpha coefficient of 0839-0915 and an observed value of reliability shows $0.876-0.935$. Based on the results of that indicators and variables valid and reliable research suggests. Here is a table determinant coefficient (R2).

Table 1. Coefficients determination (R2)

\begin{tabular}{|l|l|}
\hline Dependent variables & $\mathrm{R} 2$ \\
\hline Knowledge sharing & 0.570 \\
\hline Innovative behavior & 0.655 \\
\hline
\end{tabular}

Based on Table 1, it can be explained that the value of knowledge sharing koefiensi determinants of self-efficacy and self knowledge sharing leadership towards 0.570 . it is clear that $57.0 \%$ of the knowledge sharing knowledge sharing is affected by self-efficacy and self-leadership and the rest are other factors beyond the study models. While $65.5 \%$ of innovative behavior is influenced by knowledge sharig self-efficacy, self leadership and knowledge sharing, the remaining $34.5 \%$ were other factors beyond the study models.

Model fit in this study using Q Square Predictive Relevance (Q2) with the following formula:

$\mathrm{Q} 2=1-[(1 \mathrm{R} 2 \mathrm{Y} 1)(1 \mathrm{R} 2 \mathrm{Y} 2)]$

$=1-[(1-0570)(0655)]$

$=1-[(0.43)(0.345)]$

$=1-[0148]$

$=0852$

The results of Q2 shows that the model fit quite strong, with $85.3 \%$ of knowledge sharing relationship between selfefficacy, self leadership and knowledge sharing towards innovative behavior can be explained by this model.

Table 2. Direct and indirect knowledge sharing self-efficacy, self leadership, knowledge sharing towards innovative behavior.

\begin{tabular}{|l|l|l|l|}
\hline Direct and Indirect effect & Total effect & p-value & Information \\
\hline $\begin{array}{l}\text { Self-efficacy of knowledge sharing to } \\
\text { knowledge sharing }\end{array}$ & 0.351 & 0.003 & significant \\
\hline Self leadership to knowledge sharing & 0.458 & 0.000 & significant \\
\hline $\begin{array}{l}\text { Knowledge sharing self-efficacy to innovative } \\
\text { behavior }\end{array}$ & 0.125 & 0.212 & Non-Significant \\
\hline Self leadership to innovative behavior & 0.455 & 0.000 & significant \\
\hline Knowledge sharing to innovative behavior showledge sharing to & 0.306 & 0.002 & significant \\
\hline $\begin{array}{l}\text { Self-efficacy of knowled } \\
\text { knowledge sharing to innovative behavior }\end{array}$ & 0.013 & significant \\
\hline $\begin{array}{l}\text { Self leadership to knowledge sharing to } \\
\text { innovative behavior }\end{array}$ & 0.131 & 0.026 & significant \\
\hline
\end{tabular}

Based on Table 2 above can be explained that

1. The direct effect of knowledge sharing self-efficacy of the innovative behavior can be seen in the coefficient column 0.125 with a p-value $0.212>0.05$ it indicates that knowledge sharing self-efficacy does not affect significantly to the innovative behavior, this is in contrast to results of previous studies that have been done (Hsiao, Chang, Tu, and Chen 2011); (Hsu, Tsunghou and Liangfan 2011).

2. The direct effect of the innovative behavior of self leadership shown by the coefficient of 0.455 with 0.000 $\mathrm{p}$ value of $<0.05$ suggesting that self leadership has a positive and significant influence on innovative behavior, the results of this research line with previous research ever undertaken by (Tasan 2013); (Kor 


\section{JOURNAL OF SECURITY AND SUSTAINABILITY ISSUES}

ISSN 2029-7017/ISSN 2029-7025 (online)

2020 Volume 9 Number May

http://doi.org/10.9770/jssi.2020.9.M(12)

2016); (Park, Moon and Hyun 2014); (Hosseini, Bathae and Mohammadzadeh 2014); (Gomes, Curral, Caetano and Quinteiro 2015); (Ziyae and Heydari 2016).

3. The direct effect of self-efficacy of knowledge sharing to knowledge sharing in the show by the coefficient of 0.351 to $0.003 \mathrm{p}$ value of $<0.05$ it indicates that the self-efficacy of knowledge sharing has a positive effect on knowledge sharing and siginificant. This is according to research conducted by (Shaari, Rahman and Rajab 2014); and (Alhady, Idris, Sawal and Azmi 2011)

4. The direct effect of self leadership to knowledge sharing behavior shown by the coefficient of 0458 with $0.000 \mathrm{p}$ value of $<0.05$, it is stated that self leadership has a positive and significant influence on knowledge sharing. (Masood, Shahzad and Nosheen, 2011; Bradshaw, 2015) in his study claimed that self-leadership has an influence on knowledge sharing.

5. The direct effect of the innovative knowledge sharing behavior exhibited by the coefficient of 0.306 with $\mathrm{p}$ value $0.002<0.05$ which indicates that knowledge sharing has a positive and significant influence on innovative behavior in which the results of this research in accordance with previous studies, (Lin 2007); (Yu, Fang and Chieh 2013); (Abdallah Khalil and Divine 2012) concluded that knowledge sharing has an influence on innovative behavior.

6. The indirect effect of knowledge sharing self-efficacy of the innovative behavior through knowledge sharing demonstrated by the coefficient of 0.111 with $\mathrm{p}$ value $0.013<0.05$ which means that knowledge sharing is able to be a moderator between knowledge sharing self-efficacy to innovative behavior, whereas if a direct influence knowledge of self-efficacy have influence significant to innovative behavior.

Slef indirect influence on innovative leadership through knowledge sharing behavior shown by the coefficient of 0131 with $p$ value $0.026<0.05$ which means knowledge sharing can be a moderator between self-leadership to innovative behavior

\section{Conclusions}

Knowledge sharing self-efficacy and self-leadership are antecedents of knowledge sharing behavior, because both these variables have an influence. Knowledge sharing self efficacy and self-leadership has a direct influence on innovative behavior, which means that employees at product this classic implementing a culture of sharing both information and in a positive activity, as well as self-leadership, someone who is embodied in the form of activity, so that with the knowledge sharing and self leadership embodied in the form of activity, it will directly improve the innovative behavior. Another thing with self-efficacy of knowledge sharing which can not directly affect innovative behavior, it can be said that employees at this classic products are not confident in the capabilities.

\section{References}

Alhady, S. M., Idris, A. S. A., Sawal, M. Z., \& Azmi, A. A. (2011). Knowledge sharing behavior and individual factors: A relationship study in the IClass environment. International Conference on Management and Artificial Intelligence (IPED) 6, IACSIT Press, Bali, Indonesia, 137-141. http://dx.doi.org/10.1109/AIMSEC.2011.6010987

Asfar, B, Masood, M. (2017), Transformational Leadership, Creative Self-Efficacy, Trust in Supervisor, Uncertainty Avoidance, and Innovative Work Behavior of Nurses http://dx.doi.org/10.1177/0021886317711891

Bandura, A. (1982). Self-efficacy mechanism in human agency. American Psychologist, 37(2), 122-147 http://dx.doi.org/10.1037/0003$\underline{066 x .37 .2 .122}$

Becerra, Roy, Sanchez, Christy, Burmeister. 2016. An optimized staining technique for detection of Gram positive and Gram negative bacteria within tissue. BMC Reasearch Note, 9, 216 http://dx.doi.org/10.1186/s13104-016-1902-0

Begonja, M., Cicek, F., Balboni, B., \& Gerbin, A. (2016). Innovation and business performance determinants of smes in the adriatic region that social innovation. Economic Research Ekonomska Istrazivanja, 29(1), 1136-1149. http://dx.doi.org/10.1080/1331677X.2016.1213651 


\section{JOURNAL OF SECURITY AND SUSTAINABILITY ISSUES}

ISSN 2029-7017/ISSN 2029-7025 (online)

Bradshaw, R., Chebbi, M., \& Oztel, M. (2015). Leadership and knowledge sharing. Asian Journal of Business Research, 5(1), 1-20. http://dx.doi.org/10.14707/ajbr.150001

Carmeli, A., Weisberg, J., \& Meiter, R. (2006). Self leadership skills and innovative behavior at work.International Journal of Manpower, 27 (1), 75-90 https://doi.org/10.1108/01437720610652853

Castaneda, A., J.A. Hernandez, Rodríguez, dan C.A. Galan. 2009. Chemical Studies of Anthocyanins: A review. J. Food Chemistry. 113. Hlm 859-871. http://dx.doi.org/10.1016/j.foodchem.2008.09.001

George, J.M., \& Zhou, J. (2001). When openness to experience and conscientiousness are related to creative behavior: An interactional approach. Journal of Applied Psychology, 86(3), 513-524 http://dx.doi.org/10.1037/0021-9010.86.3.513

Haseeb, M., Haouas, I., Nasih, M., Mihardjo, L. W., \& Jermsittiparsert, K. (2020). Asymmetric impact of textile and clothing manufacturing on carbon-dioxide emissions: Evidence from top Asian economies. Energy, 196, 117094.

Hoof, B. V. \& Weenen, V. (2004). Committed to sharing commitment and CMC use as antecedents of knowledge sharing. Knowledge and Process Management, 11, 13-24 http://dx.doi.org/10.1002/kpm.187

Hosseini, S. A., Bathae, S. M., \& Mohammadzadeh, S. (2014). Does self-efficacy effect on knowledge sharing intention in e-learning system? A motivational factor analysis in Open University Malaysia (OUM). Kuwait Chapter of Arabian Journal of Business and Management Review $3(11) 35-46$

Hsiao, Y. P., Brouns, F., Bruggen, J. V., \& Sloep, P. B. (2012). Effects of peer-tutor competencies on learner cognitive load and learning performance during knowledge sharing. IADIS International Conference on Cognition and Exploratory Learning in Digital Age, 265-268. http://dx.doi.org/10.1080/10494820.2010.548068

Hsiao, H. C., Chang, J. C., Tu, Y. L., \& Chen, S. C. (2011). The Impact of self-efficacy on innovative work behavior for teacher. International Journal of Social Science and Humanity, 1(1), 31-36. http://dx.doi.org/10.1080/10494820.2010.548068

Hsu, M. L. A., Tsunghou, S., \& Liangfan, H. (2011). Creative selfefficacy and innovative behavior in a service setting: optimism as a mediator. Journal of Creative Behavior, 45(4), 258-272 http://dx.doi.org/10.1002/j.2162-6057.2011.tb01430.x

Igbaria, M. \& Iivari, J. (1995). The effects of selfefficacy on computer usage omega, 23(6), 587- 605. http://dx.doi.org/10.12691/ajss-2-5-2

Kor, B. (2016). The mediating effect of self-leadership on perceived entrepreneurial orientation and innovative work behavior in the banking sector. Springer Plus, 5, 45-58 http://dx.doi.org/10.1186/s40064-016-3556-8

Lin, H. F. (2007). Knowledge Sharing and firm innovation capability: An empirical study. 28:315-332 https://doi.org/10.1108/01437720710755272

International Journal of Manpower

Luszczynska, A., Scholz, U., \& Schwarzer, R. (2005). The general self efficacy scale: multicultural validation studies. The Journal of Psychology. 139 (5), 439-457. http://dx.doi.org/10.3200/JRLP.139.5.439-457

Kurbanoğlu, S (2010). Self-Efficacy: An Alternative Approach to the Evaluation of Information Literacy http://dx.doi.org/10.1142/9789814299701_0040

Madanchian, M., Hussein, N., \& Noordin, F. (2015). The role of smes in economic development case study of Malaysia. International Journal of Economic Research in Management, 4(3), 77-84 http://dx.doi.org/10.18775/ijmsba.1849-5664-5419.2014.19.1004

Manz, C. C. (1986). Self-leadership: Toward an expanded theory of self influence processes in organization. Academy of Management Review, 11, 585-600 http://dx.doi.org/10.5465/amr.1986.4306232

Manz, C. C. \& Neck, C. P. (2004). Mastering self leadership: Empowering your self for personal excellence. Pearson/Prentice-Hall. Upper Saddle River, NJ http://dx.doi.org/10.5465/amr.1986.4306232

Mozammel, S., Ahmed, U., Slade, H., \& Zaman, F. (2018). Digging Deep in StudentsEngagement in Bahrain: Contributions From Academic Self-Efficacy and Academic Resilience. International Journal of Management and Business Research, 8(1), 136-147. 
JOURNAL OF SECURITY AND SUSTAINABILITY ISSUES ISSN 2029-7017/ISSN 2029-7025 (online)

2020 Volume 9 Number May

http://doi.org/10.9770/jssi.2020.9.M(12)

Ofori, D., Osei, A., Mensah, S. A., \& Affum, E. K. (2015). Innovation and knowledge sharing: A new competitive advantage in the mobile telecommunication industry in Ghana. Science Journal of Business and Management, 3(5), 157-163 http://dx.doi.org/10.11648/j.sjbm.20150305.14

Park, G. R., Moon, G. W., Hyun, S. E. (2014). An impact of self leadership on innovative behavior in sports educators and understanding of advanced research. The SIJ Transactions on Industrial, Financial \& Business Management, 2(3): 117-122

11(2), 74-79. http://dx.doi.org/10.3923/ribm.2017.74.79

Shaari, R., Rahman, S. A. A., \& Rajab, A. (2014). Self-efficacy as a determined factor for knowledge sharing awareness. International Journal of Trade, Economics, and Finance, 5(1), 39-42 http://dx.doi.org/10.7763/IJTEF.2014.V5.337

Tasan, S. B. (2013). The influences of participative organizational climate and self leadership on innovative behavior and the roles of job involve ment and proactive personality: A survey in the context of smes in Izmir 2nd International Conference on Leadership, Technology and Innovation Management. Procedia-Social and Behavioral Sciences 75, 407-419. http://dx.doi.org/10.1016/j.sbspro.2013.04.045

Wang, S. and Noe, R.A. (2010) Knowledge Sharing: A Review and Directions for Future Research. Human Resource Management Review, 20,115-131. http://dx.doi.org/10.1016/j.hrmr.2009.10.001

Widyani, Sarmawa, Dewi. (2017) The roles of knowledge sharing in mediating the effect of self efficacy and self leadership toward innovative behavior. Jurnal Manajemen dan Kewirausahaan 19(2) http://dx.doi.org/10.9744/jmk.19.2.112-117

Yu, C., Fang, T., \& Chieh, C. (2013). Knowledge sharing, organizational climate, and innovative behavior: A cross-level analysis of effects. Social behavior and personality, 41(1), 143-156. doi.org/10.2224/sbp.2013.41.1.143

Ziyae, B. \& Heydari, R. (2016). Investigating the effect of selfleadership on entrepreneurs' innovation in small and medium sized enterprises. International Journal of Humanities and Cultural Studies, 2(4), 1169-1182. http://dx.doi.org/10.9774/GLEAF.978-1-909493-11-7_15

Wichitsathian, S., Nakruang, D. (2019). Knowledge integration capability and entrepreneurial orientation: case of Pakthongchai Silk Groups Residing. Entrepreneurship and Sustainability Issues, 7(2), 977-989. http://doi.org/10.9770/jesi.2019.7.2(13)

Register for an ORCID ID:

https://orcid.org/register

This work is licensed under the Creative Commons Attribution International License (CC BY).

http://creativecommons.org/licenses/by/4.0/

(c) (i) Open Access 